\title{
Cognitive Dissonance Affecting Consumer Buying Decision Making: A study Based on Khulna Metropolitan Area
}

\author{
Tarun Kanti Bose (Corresponding author) \\ Assistant Professor, Business Administration Discipline, Khulna University \\ Khulna-9208, Bangladesh \\ E-mail: tarun84ku@yahoo.com
}

\author{
Sandip Sarker \\ Independent Researcher \\ E-mail: sandip.smiling@gmail.com
}

Received: May 23, 2012

Accepted: June 19, 2012

Published: July 1, 2012

doi:10.5296/jmr.v4i3.1847

URL: http://dx.doi.org/10.5296/jmr.v4i3.1847

\begin{abstract}
The theory of "cognitive dissonance" is of great importance in consumer behavior and marketers have lots of interest in analyzing the post purchase behavior of consumers experienced by them. This paper has explored the factors that create cognitive dissonance in consumer buying decision making particularly among the consumer goods purchaser in the Khulna metropolitan area. At first a structured questionnaire has been developed measuring 10 constraints variable. The factors creating cognitive dissonance in consumer buying decision in Khulna metropolitan area have been evaluated by those 10 variables in the form of: belief, norms, customs, family status, political ideology, emotional reaction, personal performance, culture, religious value \& peer group influence. The relationship of the variables was evaluated by the survey outcomes. Results show that several factors are influential in creating cognitive dissonance among the customers of consumer goods. Some of these are family status, religious value, customs, belief etc. the study also reveals the problems and identified probable solutions to overcome these problems.
\end{abstract}

Keywords: Cognitive Dissonances, Consumer behavior, Post Purchase Behavior, Consumer Goods 


\section{Introduction}

\subsection{Background of the Study}

Consumer behavior is one of the most widely studied concepts in marketing. The better the firm understand its consumers the more likely it become successful in the marketplace. Knowledge of consumer behavior would render immense help for planning \& implementing marketing Strategies. By gaining the better understanding of the factors that affects consumer behavior marketers are in a better position to predict how consumers will respond to marketing strategies.

We know that attitudes are learned predispositions to respond an object. Customers hold attitude toward a variety of objects that are important to marketer. Also it theoretically summarizes a consumer's evaluation of an object \& represents positive \& negative feelings and behavioral tendencies. The attitude behavior link does not always hold; many other functions can affect behavior. Attitude can be positive or negative. Marketers and psychologists know that consumers' attitudes are the mixtures of belief, feelings \& tendencies lead to favorable responses resulting in purchase. An individual's attitude constitute his mental set that affect how he or she will view something such as a window provides a framework for our view into or out of a house (Newstrom \& Davis, 2000).

Cognitive dissonance is one of the most heavily studied phenomena in the history of psychology. The term cognitive dissonance describes a psychological state in which an individual's cognitions - beliefs, attitudes, and behaviors-are at odds (Festinger, 1957). Cognitive dissonance is very much related with attitude change. It is a situation in which two cognitions are inconsistent with one another. According to cognitive dissonance theory dissonance or want of harmony or inconsistency occurs when an individual holds conflicting thoughts about a belief or an attitude object. When cognitive dissonance occurs after a purchase it is called post purchase dissonance. Because purchase decision often requires some amount of compromise, post purchase dissonance is quite normal. Consumers can rationalize the decision as being wise, seek out advertisements to support their choice or look to known satisfied owners for reassurance (Schiffman \& Kanuk, 2008).

For a service related industry it is very much important for the service marketers to remove these dissonances to create positive brand image for the organization. Service industry provides a wide range of products and services to their customers. They must remain careful that their services are free from creating cognitive dissonance. They have to conduct more research over it to find out important factors that create dissonance \& reduce this. This will also help organizations to have positive customer's attitude.

This study will help to identify the influences of cognitive dissonance on consumers in purchasing goods \& services and how marketers can overcome it. The study is expected to contribute in the social \& economic perspective of the country.

\subsection{Rationale of the Study}

Satisfying customers is the ultimate objective of every marketer in all categories of goods and 
service. The post purchase behavior of a customer has been influenced by a number of social factors in which the marketer may not get any direct role. As far as durable and highly involved goods are concerned, before deciding whether the customer is satisfied or dissatisfied, they have to encounter a stage termed as Cognitive Dissonance. It means that there is a powerful motive to every individual for maintaining cognitive consistency which gives rise to irrational and sometimes maladaptive behavior (Festinger, 1957). We know that service industry is a growing industry. In offers customers to a variety of product lines. Success in this industry largely depends on delivering goods \& services efficiently. At the same time marketers should remain careful about their promotional messages so that it does not create any kind of confusion in the mind of target customers. Any form of dissonance may force customers to stitch one brand to another. Since customers are the king in the service industry it is therefore essential to satisfy customers through their offerings.

Therefore it is very much important to identify the factors that create cognitive dissonance and ensure positive customer's attitude towards their respective bands. This study will help the service organizations to find out the determinants which are dominant in creating cognitive dissonance. This study will also help to find out the probable solutions of the problems faced by the service industry in terms of cognitive dissonance.

\subsection{Objectives of the Study}

\section{Main Objective}

The objective of this study is to identify the power of cognitive dissonance in correlation of purchasing goods \& services.

\section{Sub-objectives:}

$\checkmark$ Analyze the different factors that create cognitive dissonance among the consumers.

$\checkmark \quad$ Identify \& measure the influence of these factors in purchasing goods \& services from customer's point of view.

$\checkmark \quad$ Identify problems \& measuring probable solutions from the marketers’ point of view.

\section{Literature Review and Conceptual Framework}

\subsection{Consumer Behavior}

Consumer behavior is the decision processes and acts of people involved in buying and using products. It involves purchasing \& other consumption related activities of people engaging in the exchange process. Behavior of consumer is motivated or purposive. The behavior is directed towards the goal of obtaining products or other resources. It is the activities of people engaged in actual \& potential use of market items-whether products, services, retail environments or ideas (Berkman, 1992).

The better the firm understands its consumers, the more likely it becomes successful in the marketplace. Knowledge of consumer behavior would render immense help for planning and implementing marketing strategies. Consumer response is the ultimate taste of whether a 
marketing strategy will succeed. Thus knowledge of consumer should be incorporated into every facet of a successful marketing plan. And this knowledge also helps to ensure that product continues to appeal to its core market (Schiffman \& Kanuk, 2008).

\subsection{Attitude}

Attitudes are one of the most heavily studied concepts in consumer behavior. Attitudes are learned predispositions to respond an object. Customers hold attitude toward a variety of objects that are important to marketer. Also it theoretically summarizes a consumer's evaluation of an object \& represents positive \& negative feelings and behavioral tendencies. The attitude behavior link does not always hold; many other functions can affect behavior. Attitude can be defined as a state of mind or a feeling.

Or we can say an attitude is an internal evaluation, expressed outwardly about a person, object or issue. It has been a key concept in psychology for more than a century and there are lots of definitions and lots of measures of attitude have been proposed (Solomon, 2004).

According to the most popular psychological conceptualization, the expectancy-value model, an individual's attitude toward an object represents a summary conception or evaluation based on his or her cognitions, or beliefs. Each belief associates the object with a certain attribute, and a person's overall attitude is determined by the subjective values of all the attributes, interacted with the strength of her beliefs associating the attribute with the object (Ajzen, 2001 and Malhotra, 2005).

Psychology tells us that attitudes change, and that such changes have implications for behavior. The canonical tri-component model of attitudes posits that changes in beliefs about an object tend to cause a person to attach new feelings to it, and these in turn drive changes in preferences and choices. For example, if a person obtains information about a product that causes her to have more positive beliefs about it, such as that a car gets better gas mileage than she had previously thought, she will feel more positively disposed toward it and will be more likely to buy it. It should be clear, then, that when we consider agents' tendencies with respect to economic actions; we stand on shifting ground (Grimm, 2005).

Customer attitude toward a product or service is influenced by a match of the product or service user image with the customer self-concept (Ekinci and Riley, 2003; Sirgy et al., 1992; Wang and Heitmeyer, 2005). Since, generally attitude develops over time through a learning process which is affected by reference group influences, past experience, and personality (Assael, 1981), or it is a general evaluation about something, liking or disliking, and the strength of the feelings. Attitude is an important indicator in marketing. It is assumed that it has causal link between attitudes, intentions and behavior. Hawkins, Best and Coney (1989), claimed that "because of their importance, attitudes are the focal point for a substantial amount of marketing strategy" (p.433). It means attitude should be considered in any marketing strategy.

Attitudes have been directly related to behavioral change by Loudon and Della Bitta (1993) who stated that "Behavioral change is a function of change in behavioral intentions... Changes in behavioral intentions are related to changes in attitudes" (P.422). This definition 
aims to reveal the idea that attitude contains consumer feelings and evaluations, related with a particular object. Solomon, Bamossy and Askegaard (2002) support the idea of the authors mentioned above and state that attitude is a long-lasting and common assessment of people, including oneself, objects, advertisement and a particular problem.

Another feature of attitude emphasizes that attitude is relatively permanent and reflects behavior coherently but that doesn't mean that attitude remains same forever. Schiffman and Kanuk (2004) stated that attitude could be regarded as permanent if consumer behavior matches up with consumer attitude. Attitude can be favorable and unfavorable. This means attitude can be positive or negative towards any object. According to the positive and negative attitude, consumers are subdivided into two opposite groups. Again indifference indicates that attitude is neutral. It means people have neutral attitude towards an object (Engel and Blackwell, 1998). Attitude can be of different intensity and it differs from person to person. Attitude intensity is a reliability level of an opinion about an object or how much a person in convinced in his righteousness (Rice, 1977).

Attitude measurement can help the marketers in a number of ways. Attitude consumers hold toward a particular firm and its products greatly influence the success or failure of the firms marketing strategy. If consumers hold negative attitude about one or more aspects of a firms marketing practices, they may not only stop buying the firms products, but may also influence others not to buy the particular product. Measurements of attitude help the marketers to bring appropriate changes in their products to make them more favorable to their target customers.

\subsection{Factors Affecting attitudes}

Attitudes can be influenced by many factors outside the product attributes. Social and cultural environment as well as demographic, psychographic, and geographic conditions can sometimes shape consumer behavior. Unlike personality; attitudes are expected to change as a function of experience. The term attitude is widely used in popular culture. You might be asked, "What is your attitude toward abortion?" A parent might scold, "Young man, I don't like your attitude.” Some bars even euphemistically refer to Happy as "an attitude adjustment period.” For our purpose, though attitude is lasting, general evaluation of people, object, advertisements, or issues. Anything toward which one has an attitude is called an attitude object (Solomon, 2004).

An attitude is lasting because it tends to endure over time. It is general because it applies to more than a momentary event such as hearing a loud noise, though one might over time to develop a negative attitude toward all loud noises. Consumers have attitudes toward a wide range of attitude objects, from very product specific behaviors (e.g. using White plus toothpaste rather than Colgate) to more general consumption related behavior (e.g. how often one should brush one's teeth). Attitudes help to determine whom a person choose to date, what music he or she listens to, whether he or she will recycle or discard aluminum cans, or whether he or she choose to become a consumer researcher for living (Solomon, 2004).

\subsection{Cognitive Dissonance \& Attitudes}


Cognitive dissonance can be another important factors affecting customer's attitude. It is a situation when two cognitions (knowledge or thoughts) are inconsistent with one another. Once the dissonance occurs, the individual will try to make a balance in his cognition that is, he will try to reduce dissonance. By changing his attitude he may bring cognitive consistency. An individual may experience either internal dissonance or intra-attitude dissonance if there is a conflict take place between the affective and cognitive components of an attitude. Thus marketers may bring change to consumer's attitude by influencing their cognition. It can be done by changing the beliefs of some attitude objects. For example: if a group of consumers believes that a particular brand or product is not good, the marketer of the said brand may develop an informative and persuasive advertisement to present the brand to the customers in a way so that it can bring changes to their attitudes (Festinger, 1957).

\subsection{Cognitive Dissonance}

Cognitive dissonance is a psychological phenomenon which refers to the discomfort felt at a discrepancy between what you already know or believe, and new information or interpretation. It therefore occurs when there is a need to accommodate new ideas, and it may be necessary for it to develop so that we become "open" to them makes the generation of appropriate dissonance into a major feature of tutorial (and other) teaching: he shows how to drive this kind of intellectual wedge between learners' current beliefs and "reality".

Cognitive dissonance was first investigated by Festinger (1957) and associates, arising out of a participant observation study of a cult which believed that the earth was going to be destroyed by a flood, and what happened to its members - particularly the really committed ones who had given up their homes and jobs to work for the cult — when the flood did not happen.

While fringe members were more inclined to recognize that they had made fools of themselves and to "put it down to experience", committed members were more likely to re-interpret the evidence to show that they were right all along (the earth was not destroyed because of the faithfulness of the cult members). A classical illustration of cognitive dissonance is expressed in the fable The Fox and the Grapes by Aesop. In the story, a fox sees some high-hanging grapes and wishes to eat them. When the fox is unable to think of a way to reach them, he decides that the grapes are probably not worth eating, with the justification the grapes probably are not ripe or that they are sour (hence "sour grapes"). This example follows a pattern: one desires something, finds it unattainable, and reduces one's dissonance by criticizing it. Jon Elster calls this pattern "adaptive preference formation". Smoking is a common example of cognitive dissonance because it is widely accepted that cigarettes can cause lung cancer, and smokers must reconcile their habit with the desire to live long and healthy lives. In terms of the theory, the desire to live a long life is dissonant with the activity of doing something that will most likely shorten one's life. The tension produced by these contradictory ideas can be reduced by any number of changes in cognitions and behaviors, including quitting smoking, denying the evidence linking smoking to lung cancer, or justifying one's smoking. For example, smokers could rationalize their behavior by concluding that only a few smokers become ill, that it only happens to very heavy smokers, 
or that if smoking does not kill them, something else will (Wikipedia, cognitive dissonance).

\subsection{Factors Creating Cognitive Dissonance}

People tend to seek steadiness in their beliefs and perceptions. The term cognitive dissonance is used to describe the feeling of discomfort that results from holding two conflicting beliefs. When there is a incongruity between beliefs and behaviors, something must change in order to eliminate or reduce the dissonance. Several factors are responsible for creating cognitive dissonance. Some of these are like values, belief, attitudes, customs, political philosophy, religious value, emotional reaction, norms, culture, social status, peer group influence etc.

People living in a particular culture may hold a strong belief that he or she should purchase that product that must be accepted by that particular culture. In purchasing products conflict may arise regarding whether to purchase or not. Will it be accepted by my society? This situation creates cognitive dissonance. Besides people may have different values, belief, customs which might create dissonance in case of purchasing products. A religious value is one of the most important factors which are responsible for generating cognitive dissonance. People of different religion purchase items based on their religious belief. Some items are strongly prohibited by some religion and when people purchasing those, it creates dissonance. In addition to this political value, emotional reactions, social status also affect purchase decision and thus creating cognitive dissonance (Bhasin, 2010).

\subsection{Importance of Measuring Cognitive Dissonance in Service and Product Industry}

In the area of service marketing customer's attitude plays an important role for the marketers. It is one of the important determinants in buying behavior. Marketers should always be concerned about the service related issues which directly affects the customer's attitude. Service industry is a very competitive industry. Success in this industry largely depends on delivering quality products to the target markets. Cognitive dissonance is an obstacle in this industry. Marketers therefore should be very careful in delivering products to the target markets in order to avoid generating cognitive dissonance (Festinger, 1957)

Cognitive dissonance theory suggests that dissonance or inconsistency occurs when an individual holds conflicting thoughts about a belief or an object. Once the dissonance occurs the individual will try to make a balance in his cognition, which is he will try to reduce dissonance. By changing his attitudes he may bring cognitive consistency. An individual may experience either the internal dissonance or the inter-attitude dissonance. Marketers should also be careful that the message which will be delivered to the target customers must be free from any dissonance. That is it must be matched with the customer's culture, values, belief, religious value, political philosophy, emotional reaction. Thus a marketer may bring change in consumer's attitudes by influencing their cognition.

This may be done with the help of marketing promotional tools. For example if a group of customer believes that a particular brand of product is not good, the marketer of that said brand may develop an informative and persuasive advertisement to present the brand to the customers in a way that may bring change in their attitudes. As the customers get new information, which were not known to them, they may change their attitudes towards their 
brand. This may happen as consumer's cognitions change. Marketers may also try to change the feelings or the affective component of customer's attitudes. By presenting the brand in an emotional context marketers may also bring changes in consumers mind. Marketers may also try to create dissonance towards their competing brands in the mind of target customers. Thus it is important for the service marketers to reduce cognitive dissonance from the customer's mind \& therefore survive competition in the service industry.

\subsection{Relevant Earlier Researches}

Several researches have been conducted on cognitive dissonance and found out the ways of reducing this from marketer's point of view. Hamza \& Zakkariya (2012) has conducted named "Determinants of cognitive dissonance and its relative importance to consumer product purchase”. On their study they particularly focused on the cognitive dissonance and its outcome behaviors among university students belonging to the age group of 19 to 25, who bought a durable product very recently. Results shows that various determinants posses different degree of influences in developing Cognitive dissonance to customers.

Egan et al., (2007) have conducted a research named "The Origins of Cognitive Dissonance: Evidence from Children and Monkeys. The study was expected subjects to change their attitude toward the unchosen alternative, deeming it less valuable. Then they presented subjects with a choice between the unchosen option and an option that was originally as attractive as both options in the first choice. Both groups preferred the novel over the unchosen option in this experimental condition, but not in a control condition in which they did not take part in the first decision. These results provide the first evidence of decision rationalization in children and nonhuman primates.

Another study done by Lieberman et al., (2001) named “do amnesics exhibit cognitive dissonance reductions? The role of explicit memory and attention in attitude change". It identified the roles of explicit memory and attentional resources in the process of behavior-induced attitude change. Although most theories of attitude change (cognitive dissonance and self-perception theories) assume an important role for both mechanisms, they proposed that behavior-induced attitude change can be a relatively automatic process that does not require explicit memory for, or consciously controlled processing of, the discrepancy between attitude and behavior. Using a free-choice paradigm, they found that both amnesics and normal participants under cognitive load showed as much attitude change as did control participants.

Kaish (1967) conducted a research on cognitive dissonance titled "Cognitive Dissonance and the Classification of Consumer Goods" to find out its impact on consumer goods items. Korgaonkar \& Moschis (1982) conducted a study titled “An Experimental Study of Cognitive Dissonance, Product Involvement, Expectations, Performance and Consumer Judgment of Product Performance” to find out its significance on products \& customers.

\subsection{Significance of this Study from Earlier Word Wide Researches Contexts and Adding Value} to Existing Literatures

A large number of studies have been conducted in the field of Cognitive Dissonance to 
analyze its determinants (Montgomery \& Barnes 1993, Oshikawa 1972). This study has been conducted considering many variables under several dimensions that provide the clear evidences of the different types of factors creating cognitive dissonance among the people in the Khulna metropolitan area. Customers participated in answering questions directly. And many researches in the same field have been taken into consideration when measuring the customer's satisfaction. The knowledge have been developed from the earlier researches utilized here to make the study significant. The study will help the consumer goods industry and the other firms as well. In the service industry especially in the consumer goods success largely depends on satisfying target customers. This study will definitely help the service marketers to identify the factors that create cognitive dissonance and identify probable solution to reduce this dissonance to gain positive customer's attitudes. In the other service related industry like banking industry can also be benefited by this study to reduce post purchase dissonance. This study also helps to contribute in the existing literature.

\section{Materials and Methods}

\subsection{Research Questions}

Research questions have been determined after reviewing the existing literature and also evaluating the contexts of local businesses and market set-up. In the process of setting the research questions -the prospective future contribution of this research work also has been considered. That was a major concern because the study should be able to contribute something in the existing scientific literatures and also for the development of the country and society. The following research questions have been set afterwards:

- Research Question 1: What are the factors that create cognitive dissonance in consumer buying behavior?

- $\quad$ Research Question 2: What initiatives can be done to reduce this dissonance?

\subsection{Sub-Questions}

\section{Sub-Questions of Research Question 1:}

- What are the descriptive statistical outcomes of different available problems?

- What are the major problems areas under different problems?

- What is co-relation among different problem areas?

- What is the condition of the factors among different problems?

\section{Sub-Questions of Research Question 2:}

- What the service organizations can do?

- What the customers themselves can do?

\subsection{Research Design}

In order to solve the above mentioned research questions and corresponding sub-questions 
this study has been adopted the following research design comprising data collection and analysis. This study has utilized survey research methodology. A highly structured questionnaire was developed based on discussions with selected university faculty, and authority of print media and literature review. The pre-test was conducted by trained graduate students for wording, layout, content validity, and determining main data collection methods. Those students were the bachelor students of the Business Administration Department of Khulna University, Bangladesh. They were involved both in pre-testing the questionnaire and also in data collection campaign. They were provided with adequate training before taking their part in the research campaign. Those training have given them necessary idea about the questionnaire and also how to conduct an interview with questionnaire with different tour operators. University faculty of Business Administration Department, Khulna University; who are expert in research and data collection has provided them the training prior to the data collection.

\subsection{The Population}

The population of this study is all the customers of consumer goods industry in the Khulna metropolitan region.

\subsection{Sampling Design}

A total of 100 customers from the population sectors have been selected with following the simple random sampling procedure. Sample size has been selected after reviewing a lot of literature and study conducted on similar field. The accuracy of representation also been assured from the evidences of those earlier researches. A total of 100 customers have taken part in interview with structured questionnaire.

\subsection{Instrument Development}

\section{Questionnaire}

Research conduction with the help of questionnaire is the most popular method irrespective of the sectors. It is used in almost every field and business sector is no exception. This study has dealt with factors that create cognitive dissonance among the customers of consumer goods industry in the Khulna region. The research design of the study elaborates that the constraints were identified from the responses of the customers, as they know the best about the problems they normally and frequently faced while purchasing. For serving that purpose it is always require preparing a structured questionnaire. The questionnaire for the study was prepared on the basis of literatures review and context of the region. It consist 40 questions of 10 concerning variables in the form of variety of variables e.g. belief, norms, customs, cultures, political ideology, religious values, personal performance, emotional reactions etc. It has been prepared by using a five-point Likert scale $(1=$ strongly disagree and $5=$ strongly agree).

\subsection{Data Collection}

The process of gathering information by trainees was facilitated through a face to face interview of the customers. Bachelor Students of Business Administration Discipline of 
Khulna University was took part in the survey conduction. One month starting from the mid of September to mid November 2011 was taken for survey conduction and data collection. Apart from that a lot of secondary data will also be collected from different published sources.

\subsection{Data Analysis}

The data analysis has been done by utilizing both quantitative and qualitative analysis techniques. This study has conducted the data analysis with the application of SPSS software version 15.0. Data has been analyzed with the help of the literatures of the previous researches of the same field. In order to make the analysis fruitful and goal directed special attention has been given towards fulfilling all the research questions and sub-questions successfully by the process of data analysis. The following four research questions and their corresponding sub questions will be analyzed by utilizing the following respective data analysis techniques:

- Research Question 1: What are the factors that create cognitive dissonance in consumer buying behavior?

- Sub-Questions:

\section{Sub-Questions of Research Question 1:}

- What are the descriptive statistical outcomes of different available problems?

- What are the major problems areas under different problems?

- What is co-relation among different problem areas?

- What is the condition of the factors among different problems?

In order to fulfill the first research question and its sub-questions: first the outcome of the survey was tabulated. The mean, standard deviation and coefficient of variation scores of the 10 major problem variables was analyzed from the tabular presentation. Then factor analysis was done with the principal component analysis. The 8 independent variables of the study were generated relevant items from the questionnaire survey and those were being purified and validated through the factor analysis and internal consistency. The Verimax rotation procedure and Eigen value plot has been utilized to identify the number of components. From the gross outcome the ranking of the 8constraints was taken place from the mean score. Along with that the correlation were also identified with using bivariate analysis among the variables of all the constraints dimension. The major problems have been analyzed by utilizing qualitative analysis techniques by utilizing the response of the tour operators. It was done with the assistance of a number of studies in this field.

- $\quad$ Research Question 2: What initiatives can be done to reduce this dissonance?

\section{Sub-Questions of Research Question 2:}

- What the service organizations can do? 
- What the customers themselves can do?

In order to fulfill the requirements of the research question 2 and it's corresponding sub-questions-descriptive and qualitative analysis has been done for suggesting the improving ways for the customers \& service marketers. In order to do so the problem detection and extremity as well as the factor outputs were also considered and thus assisted a lot for the problem eradication suggestion process.

\subsection{Measurement of Variables}

The survey questionnaire has measured 10 constraints variables. The factors creating cognitive dissonance in consumer buying decision in Khulna metropolitan area have been evaluated by those 10 variables in the form of: belief, norms, family status, political ideology, emotional reaction, personal performance, customs, culture, religious value \& peer group influence. Here, the marketer's problem in Khulna region is the dependent variable and those 8 constraints are the independent variables. The relationship of the variables was evaluated by the survey outcomes.

\section{Findings and Analysis}

\subsection{Belief Descriptive Statistics}

\begin{tabular}{|c|c|c|c|c|c|}
\hline & $\mathrm{N}$ & Minimum & Maximum & Mean & Std. Deviation \\
\hline Belief influencing purchase & 100 & 2 & 5 & 3.63 & .971 \\
\hline $\begin{array}{l}\text { Influence of earlier belief in } \\
\text { selecting brands }\end{array}$ & 100 & 1 & 5 & 3.42 & .901 \\
\hline Frequency of changing belief & 100 & 1 & 5 & 3.38 & .896 \\
\hline Conflict \& belief in purchasing & 100 & 2 & 5 & 3.21 & .795 \\
\hline Valid N (list wise) & 100 & & & 3.41 & 0.89075 \\
\hline
\end{tabular}

\section{Correlations}

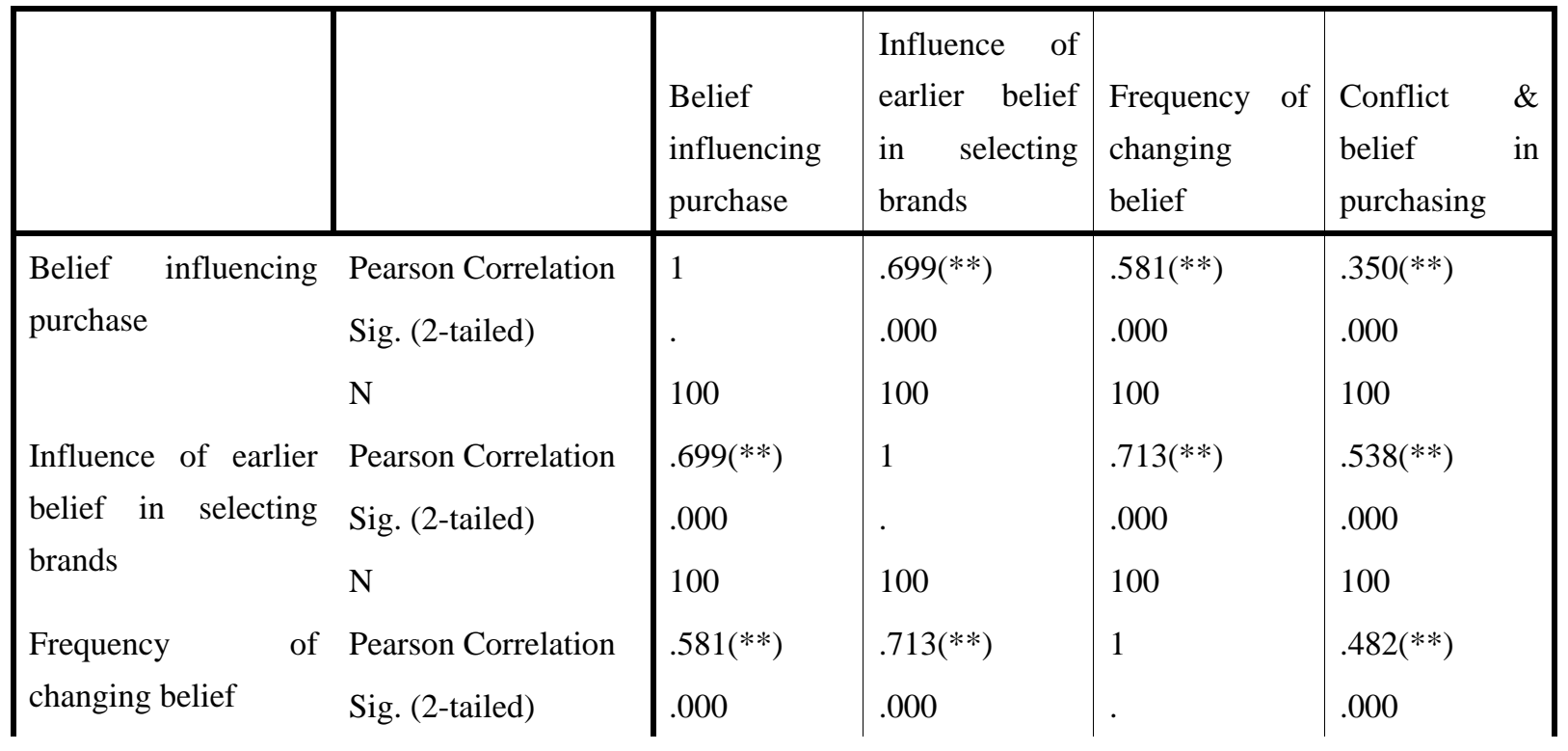




\begin{tabular}{|ll|l|l|l|l|}
\hline & $\mathrm{N}$ & 100 & 100 & 100 & 100 \\
Conflict \& belief in & Pearson Correlation & $.350\left(^{* *}\right)$ & $.538(* *)$ & $.482(* *)$ & 1 \\
purchasing & Sig. (2-tailed) & .000 & .000 & .000 &. \\
& $\mathrm{~N}$ & 100 & 100 & 100 & 100 \\
\hline
\end{tabular}

** Correlation is significant at the 0.01 level (2-tailed). 


\section{I Macrothink}

\section{Total Variance Explained}

\begin{tabular}{|l|l|l|l|l|l|l|}
\hline \multirow{2}{*}{ Component } & \multicolumn{3}{|l|}{ Initial Eigen values } & \multicolumn{3}{l|}{ Extraction Sums of Squared Loadings } \\
& Total & \% of Variance & Cumulative \% & Total & \% of Variance & Cumulative \% \\
\hline 1 & 2.703 & 67.563 & 67.563 & 2.703 & 67.563 & 67.563 \\
2 & .669 & 16.719 & 84.282 & & & \\
4 & .392 & 9.791 & 94.072 & & & \\
\hline
\end{tabular}

Extraction Method: Principal Component Analysis.

Observation 1: From the analysis of descriptive statistics we can see that the obtained mean of the dimension belief is 3.41. The highest mean has been obtained as 3.63 in case of belief in purchase which is very influential factor in cognitive dissonance. The overall outcome has found that factors are influential. The lowest score is 3.21 for conflict \& belief in purchasing. The standard deviation score of 0.89075 is high that means the variability among the dimension is spread widely. The correlation matrix in this dimension shows hundred percent positive correlations among the entire questions variable \& all the four questions of this dimension have internal consistent relationship and also relationship has been derived in the responses of the buying behavior. There is a high degree of correlation between Frequency of changing belief \& Influence of earlier belief in selecting brands. Variance analysis clearly shows first two questions of the dimension covers $84 \%$ of the total variance. That represent that the first two questions are of great importance among all the questions of the dimensions.

\subsection{Norms Descriptive Statistics}

\begin{tabular}{|c|c|c|c|c|c|}
\hline & $\mathrm{N}$ & Minimum & Maximum & Mean & Std. Deviation \\
\hline $\begin{array}{l}\text { Giving emphasis on norms in } \\
\text { purchasing }\end{array}$ & 100 & 2 & 5 & 3.72 & .637 \\
\hline $\begin{array}{l}\text { Influence of norms in purchasing } \\
\text { right products }\end{array}$ & 100 & 2 & 5 & 3.85 & .744 \\
\hline $\begin{array}{l}\text { Purchasing prohibited items \& } \\
\text { norms }\end{array}$ & 100 & 3 & 5 & 3.92 & .662 \\
\hline $\begin{array}{l}\text { Avoidance of a product in relation } \\
\text { to norms }\end{array}$ & 100 & 3 & 5 & 3.79 & .591 \\
\hline Valid N (list wise) & 100 & & & 3.82 & 0.6585 \\
\hline
\end{tabular}




\section{Correlations}

\begin{tabular}{|c|c|c|c|c|c|}
\hline & & $\begin{array}{l}\text { Giving } \\
\text { emphasis on } \\
\text { norms in } \\
\text { purchasing }\end{array}$ & $\begin{array}{l}\text { Influence of } \\
\text { norms in } \\
\text { purchasing } \\
\text { right products }\end{array}$ & $\begin{array}{l}\text { Purchasing } \\
\text { prohibited } \\
\text { items \& } \\
\text { norms. }\end{array}$ & $\begin{array}{l}\text { Avoidance } \\
\text { of a product } \\
\text { in relation } \\
\text { to norms }\end{array}$ \\
\hline \multirow{3}{*}{$\begin{array}{l}\text { Giving emphasis on } \\
\text { norms in purchasing }\end{array}$} & Pearson Correlation & 1 & $.721(* *)$ & $.641(* *)$ & $.701(* *)$ \\
\hline & Sig. (2-tailed) & . & .000 & .000 & .000 \\
\hline & $\mathrm{N}$ & 100 & 100 & 100 & 100 \\
\hline \multirow{3}{*}{$\begin{array}{l}\text { Influence of norms in } \\
\text { purchasing right } \\
\text { products. }\end{array}$} & Pearson Correlation & $.721(* *)$ & 1 & $.571(* *)$ & $.686(* *)$ \\
\hline & Sig. (2-tailed) & .000 & . & .000 & .000 \\
\hline & $\mathrm{N}$ & 100 & 100 & 100 & 100 \\
\hline \multirow{3}{*}{$\begin{array}{l}\text { Purchasing prohibited } \\
\text { items \& norms }\end{array}$} & Pearson Correlation & $.641(* *)$ & $.571(* *)$ & 1 & $.757(* *)$ \\
\hline & Sig. (2-tailed) & .000 & .000 & . & .000 \\
\hline & $\mathrm{N}$ & 100 & 100 & 100 & 100 \\
\hline \multirow{3}{*}{$\begin{array}{l}\text { Avoidance of a product } \\
\text { in relation to norms }\end{array}$} & Pearson Correlation & $.701(* *)$ & $.686(* *)$ & $.757(* *)$ & 1 \\
\hline & Sig. (2-tailed) & .000 & .000 & .000 & \\
\hline & $\mathrm{N}$ & 100 & 100 & 100 & 100 \\
\hline
\end{tabular}

** Correlation is significant at the 0.01 level (2-tailed)

\section{Total Variance Explained}

\begin{tabular}{|l|l|l|l|l|l|l|}
\hline \multirow{2}{*}{ Component } & \multicolumn{2}{l|}{ Initial Eigen values } & \multicolumn{2}{l|}{ Extraction Sums of Squared Loadings } \\
\cline { 2 - 7 } & Total & \% of Variance & Cumulative \% & Total & \% of Variance & Cumulative \% \\
\hline 1 & 3.040 & 76.001 & 76.001 & 3.040 & 76.001 & 76.001 \\
2 & .465 & 11.621 & 87.622 & & & \\
3 & .278 & 6.951 & 94.572 & & & \\
4 & .217 & 5.428 & 100.000 & & & \\
\hline
\end{tabular}

Extraction Method: Principal Component Analysis.

Observation 2: From the analysis of descriptive statistics we can see that the obtained mean of the dimension norms is 3.82. The highest mean has been obtained as 3.92 in case of Purchasing prohibited items \& norms which is a very dominant factor in creating cognitive dissonance. The standard deviation score of 0.6585 is high that means the variability among the dimension is spread widely. If we look at the correlation matrix we can see hundred percent positive correlations among the entire questions variable \& all the four questions of this dimension have internal consistent relationship and also relationship has been derived in 
the responses of the purchasing pattern. There is a high degree of correlation between Influence of norms in purchasing right products \& giving emphasis on norms in purchasing. Variance analysis also shows first two questions of the dimension covers $87.622 \%$ of the total variance. That represent that the first two questions are of great importance among all the questions of the dimensions.

\subsection{Customs Descriptive Statistics}

\begin{tabular}{|c|c|c|c|c|c|}
\hline & $\mathrm{N}$ & Minimum & Maximum & Mean & Std. Deviation \\
\hline Holding family tradition & 100 & 2 & 5 & 3.71 & .537 \\
\hline $\begin{array}{l}\text { Purchasing } \quad \& \quad \text { family } \\
\text { acceptance }\end{array}$ & 100 & 2 & 5 & 3.83 & .779 \\
\hline $\begin{array}{l}\text { Maintaining customs \& } \\
\text { purchasing }\end{array}$ & 100 & 2 & 5 & 3.77 & .750 \\
\hline $\begin{array}{l}\text { Following parents' purchasing } \\
\text { pattern }\end{array}$ & 100 & 3 & 5 & 3.47 & .627 \\
\hline Valid N (list wise) & 100 & & & 3.695 & 0.67325 \\
\hline
\end{tabular}

\section{Correlations}

\begin{tabular}{|c|c|c|c|c|c|}
\hline & & $\begin{array}{l}\text { Holding } \\
\text { family } \\
\text { tradition }\end{array}$ & $\begin{array}{l}\text { Purchasing \& } \\
\text { family } \\
\text { acceptance }\end{array}$ & $\begin{array}{l}\text { Maintaining } \\
\text { customs \& } \\
\text { purchasing }\end{array}$ & $\begin{array}{l}\text { Following } \\
\text { parents' } \\
\text { purchasing } \\
\text { pattern }\end{array}$ \\
\hline \multirow{3}{*}{$\begin{array}{l}\text { Holding } \\
\text { tradition }\end{array}$} & Pearson Correlation & 1 & $.629(* *)$ & $.660(* *)$ & $.379(* *)$ \\
\hline & Sig. (2-tailed) & . & .000 & .000 & .000 \\
\hline & $\mathrm{N}$ & 100 & 100 & 100 & 100 \\
\hline \multirow{3}{*}{$\begin{array}{l}\text { Purchasing \& family } \\
\text { acceptance }\end{array}$} & Pearson Correlation & $.629(* *)$ & 1 & $.606\left(^{* *}\right)$ & $.579(* *)$ \\
\hline & Sig. (2-tailed) & .000 & . & .000 & .000 \\
\hline & $\mathrm{N}$ & 100 & 100 & 100 & 100 \\
\hline \multirow{3}{*}{$\begin{array}{l}\text { Maintaining customs } \\
\text { \& purchasing }\end{array}$} & Pearson Correlation & $.660(* *)$ & $.606(* *)$ & 1 & $.383(* *)$ \\
\hline & Sig. (2-tailed) & .000 & .000 & . & .000 \\
\hline & $\mathrm{N}$ & 100 & 100 & 100 & 100 \\
\hline \multirow{3}{*}{$\begin{array}{l}\text { Following parents' } \\
\text { purchasing pattern }\end{array}$} & Pearson Correlation & $.379(* *)$ & $.579(* *)$ & $.383(* *)$ & 1 \\
\hline & Sig. (2-tailed) & .000 & .000 & .000 & . \\
\hline & $\mathrm{N}$ & 100 & 100 & 100 & 100 \\
\hline
\end{tabular}

** Correlation is significant at the 0.01 level (2-tailed). 


\section{Il Macrothink}

\section{Total Variance Explained}

\begin{tabular}{|l|l|l|l|l|l|l|}
\hline \multirow{2}{*}{ Component } & \multicolumn{3}{|l|}{ Initial Eigen values } & \multicolumn{3}{l|}{ Extraction Sums of Squared Loadings } \\
& Total & \% of Variance & Cumulative \% & Total & \% of Variance & Cumulative \% \\
\hline 1 & 2.632 & 65.791 & 65.791 & 2.632 & 65.791 & 65.791 \\
2 & .709 & 17.728 & 83.518 & & & \\
3 & .347 & 8.686 & 92.205 & & & \\
\hline
\end{tabular}

Extraction Method: Principal Component Analysis.

Observation 3: From the analysis of descriptive statistics we can see that the obtained mean of the dimension customs is 3.69. The highest mean has been obtained as 3.83 in case of Purchasing \& family acceptance which is a very prevailing factor in creating cognitive dissonance. The standard deviation score of 0.67325 is high that means the variability among the dimension is spread widely. In the correlation matrix there shows hundred percent positive correlations among the entire questions variable \& all the four questions of this dimension have internal consistent relationship and also relationship has been derived in the responses of the purchasing pattern. There is a high degree of correlation between Purchasing \& family acceptance \& Holding family tradition. There is also positive correlation between Following parents' purchasing pattern \& Holding family tradition but the degree of correlation is lower. Variance analysis also shows first two questions of the dimension covers $83.518 \%$ of the total variance. That represent that the first two questions are of great importance among all the questions of the dimensions.

\subsection{Culture: Descriptive Statistics}

\begin{tabular}{|c|c|c|c|c|c|}
\hline & $\mathrm{N}$ & Minimum & Maximum & Mean & Std. Deviation \\
\hline Social heritage \& purchasing & 100 & 2 & 4 & 3.08 & .761 \\
\hline $\begin{array}{lll}\text { Cultural prejudices } \quad \& \\
\text { purchasing }\end{array}$ & 100 & 2 & 5 & 3.24 & .754 \\
\hline $\begin{array}{l}\text { Wearing national dress } \\
\text { willingly }\end{array}$ & 100 & 1 & 5 & 2.84 & .662 \\
\hline $\begin{array}{l}\text { Following culture just to avoid } \\
\text { condemnation }\end{array}$ & 100 & 1 & 4 & 2.48 & .703 \\
\hline Valid N (list wise) & 100 & & & 2.91 & 0.72 \\
\hline
\end{tabular}




\section{Correlations}

\begin{tabular}{|c|c|c|c|c|c|}
\hline & & $\begin{array}{l}\text { Social } \\
\text { heritage \& } \\
\text { purchasing }\end{array}$ & $\begin{array}{l}\text { Cultural } \\
\text { prejudices \& } \\
\text { purchasing }\end{array}$ & $\begin{array}{l}\text { Wearing } \\
\text { national dress } \\
\text { willingly }\end{array}$ & $\begin{array}{l}\text { Following } \\
\text { culture just to } \\
\text { avoid } \\
\text { condemnation }\end{array}$ \\
\hline $\begin{array}{l}\text { Social heritage \& } \\
\text { purchasing }\end{array}$ & $\begin{array}{l}\text { Pearson Correlation } \\
\text { Sig. (2-tailed) } \\
\mathrm{N}\end{array}$ & 100 & $\begin{array}{l}.653(* *) \\
.000 \\
100\end{array}$ & $\begin{array}{l}.607(* *) \\
.000 \\
100\end{array}$ & $\begin{array}{l}-.469(* *) \\
.000 \\
100\end{array}$ \\
\hline $\begin{array}{l}\text { Cultural prejudices \& } \\
\text { purchasing }\end{array}$ & $\begin{array}{l}\text { Pearson Correlation } \\
\text { Sig. (2-tailed) } \\
\mathrm{N}\end{array}$ & $\begin{array}{l}.653(* *) \\
.000 \\
100\end{array}$ & $\begin{array}{l}1 \\
\cdot \\
100\end{array}$ & $\begin{array}{l}.583(* *) \\
.000 \\
100\end{array}$ & $\begin{array}{l}-.315(* *) \\
.001 \\
100\end{array}$ \\
\hline $\begin{array}{l}\text { Wearing national } \\
\text { dress willingly }\end{array}$ & $\begin{array}{l}\text { Pearson Correlation } \\
\text { Sig. (2-tailed) } \\
\mathrm{N}\end{array}$ & $\begin{array}{l}.607(* *) \\
.000 \\
100\end{array}$ & $\begin{array}{l}.583(* *) \\
.000 \\
100\end{array}$ & $\begin{array}{l}1 \\
\cdot \\
100\end{array}$ & $\begin{array}{l}-.267(* *) \\
.007 \\
100\end{array}$ \\
\hline $\begin{array}{l}\text { Following culture just } \\
\text { to avoid } \\
\text { condemnation }\end{array}$ & $\begin{array}{l}\text { Pearson Correlation } \\
\text { Sig. (2-tailed) } \\
\mathrm{N}\end{array}$ & $\begin{array}{l}-.469(* *) \\
.000 \\
100\end{array}$ & $\begin{array}{l}-.315(* *) \\
.001 \\
100\end{array}$ & $\begin{array}{l}-.267(* *) \\
.007 \\
100\end{array}$ & $\begin{array}{l}1 \\
\cdot \\
100\end{array}$ \\
\hline
\end{tabular}

** Correlation is significant at the 0.01 level (2-tailed).

\section{Total Variance Explained}

\begin{tabular}{|l|l|l|l|l|l|l|}
\hline \multirow{2}{*}{ Component } & \multicolumn{2}{l|}{ Initial Eigen values } & \multicolumn{3}{l|}{ Extraction Sums of Squared Loadings } \\
\cline { 2 - 7 } & Total & \% of Variance & Cumulative \% & Total & \% of Variance & Cumulative \% \\
\hline 1 & 2.481 & 62.020 & 62.020 & 2.481 & 62.020 & 62.020 \\
2 & .790 & 19.745 & 81.765 & & & \\
3 & .417 & 10.420 & 92.185 & & & \\
4 & .313 & 7.815 & 100.000 & & & \\
\hline
\end{tabular}

Extraction Method: Principal Component Analysis.

Observation 4: Descriptive statistics shows that the obtained mean of the dimension culture is 2.91 which are very much lower. The highest mean has been obtained as 3.08 in case of social heritage \& purchasing which is a very influential factor in creating cognitive dissonance. The standard deviation score is 0.72 , which means the variability among the dimension. The correlation matrix in this dimension shows both negative and positive correlation between the variables. There is a high degree of correlation between Social 
heritage \& purchasing \& cultural prejudices \& purchasing. There is high degree of negative correlation between Social heritage \& purchasing \& following culture just to avoid condemnation. Variance analysis also shows first two questions of the dimension covers $81.76 \%$ of the total variance. That represent that the first two questions are of great importance among all the questions of the dimensions.

\subsection{Political Ideology Descriptive Statistics}

\begin{tabular}{|c|c|c|c|c|c|}
\hline & $\mathrm{N}$ & Minimum & Maximum & Mean & Std. Deviation \\
\hline $\begin{array}{l}\text { Political philosophy \& } \\
\text { purchase }\end{array}$ & 100 & 1 & 4 & 2.32 & .680 \\
\hline $\begin{array}{l}\text { Preference of products based } \\
\text { on peer's choice }\end{array}$ & 100 & 1 & 5 & 2.70 & .823 \\
\hline $\begin{array}{l}\text { Maintaining political ideology } \\
\text { in purchasing strongly }\end{array}$ & 100 & 1 & 5 & 2.52 & .882 \\
\hline $\begin{array}{l}\text { Preference of products offered } \\
\text { by same peer }\end{array}$ & 100 & 1 & 5 & 2.76 & .830 \\
\hline Valid N (list wise) & 100 & & & 2.575 & 0.80375 \\
\hline
\end{tabular}

\section{Correlations}

\begin{tabular}{|c|c|c|c|c|c|}
\hline & & $\begin{array}{l}\text { Political } \\
\text { philosophy } \\
\text { \& purchase }\end{array}$ & $\begin{array}{l}\text { Preference of } \\
\text { products } \\
\text { based on } \\
\text { peer's choice }\end{array}$ & $\begin{array}{l}\text { Maintaining } \\
\text { political } \\
\text { ideology in } \\
\text { purchasing } \\
\text { strongly }\end{array}$ & $\begin{array}{l}\text { Preference of } \\
\text { products } \\
\text { offered by } \\
\text { same peer }\end{array}$ \\
\hline \multirow{3}{*}{$\begin{array}{l}\text { Political philosophy \& } \\
\text { purchase. }\end{array}$} & Pearson Correlation & 1 & $.589(* *)$ & $.461(* *)$ & .137 \\
\hline & Sig. (2-tailed) & . & .000 & .000 & .173 \\
\hline & $\mathrm{N}$ & 100 & 100 & 100 & 100 \\
\hline \multirow{3}{*}{$\begin{array}{l}\text { Preference of products } \\
\text { based on peer's choice }\end{array}$} & Pearson Correlation & $.589(* *)$ & 1 & $.496(* *)$ & .071 \\
\hline & Sig. (2-tailed) & .000 & . & .000 & .483 \\
\hline & $\mathrm{N}$ & 100 & 100 & 100 & 100 \\
\hline \multirow{3}{*}{$\begin{array}{l}\text { Maintaining political } \\
\text { ideology in purchasing } \\
\text { strongly }\end{array}$} & Pearson Correlation & $.461(* *)$ & $.496(* *)$ & 1 & $.490(* *)$ \\
\hline & Sig. (2-tailed) & .000 & .000 & . & .000 \\
\hline & $\mathrm{N}$ & 100 & 100 & 100 & 100 \\
\hline \multirow{3}{*}{$\begin{array}{l}\text { Preference of products } \\
\text { offered by same peer }\end{array}$} & Pearson Correlation & .137 & .071 & $.490(* *)$ & 1 \\
\hline & Sig. (2-tailed) & .173 & .483 & .000 & . \\
\hline & $\mathrm{N}$ & 100 & 100 & 100 & 100 \\
\hline
\end{tabular}

** Correlation is significant at the 0.01 level (2-tailed). 
Total Variance Explained

\begin{tabular}{|l|l|l|l|l|l|l|}
\hline \multirow{2}{*}{ Component } & \multicolumn{3}{|l|}{ Initial Eigen values } & \multicolumn{3}{l|}{ Extraction Sums of Squared Loadings } \\
\cline { 2 - 7 } & Total & \% of Variance & Cumulative \% & Total & \% of Variance & Cumulative \% \\
\hline 1 & 2.171 & 54.278 & 54.278 & 2.171 & 54.278 & 54.278 \\
2 & 1.059 & 26.487 & 80.765 & 1.059 & 26.487 & 80.765 \\
3 & .434 & 10.862 & 91.627 & & & \\
4 & .335 & 8.373 & 100.000 & & & \\
\hline
\end{tabular}

Extraction Method: Principal Component Analysis.

Observation 5: Descriptive statistics shows that the obtained mean of the dimension political ideology is 2.57 which are a bit lower. The highest mean has been obtained as 2.76 in case of Preference of products offered by same peer which is a very dominant factor in creating cognitive dissonance. The standard deviation score is 0.80375 , which means the variability among the dimension. In the correlation matrix there lays hundred percent positive correlations among the entire questions variable \& all the four questions of this dimension have internal consistent relationship and also relationship has been derived in the responses of the purchasing pattern. There is a high degree of correlation between Preference of products based on peer's choice \& Political philosophy \& purchase. There is also correlation between maintaining political ideology in purchasing strongly \& Political philosophy and purchase but the degree of correlation is slightly lower. Variance analysis also shows first two questions of the dimension covers $80.76 \%$ of the total variance. That represent that the first two questions are of great importance among all the questions of the dimensions.

\subsection{Religious value Descriptive Statistics}

\begin{tabular}{|c|c|c|c|c|c|}
\hline & $\mathrm{N}$ & Minimum & Maximum & Mean & Std. Deviation \\
\hline Religious values \& purchasing & 100 & 2 & 5 & 3.75 & .770 \\
\hline $\begin{array}{l}\text { Prohibited item purchase \& } \\
\text { religious value }\end{array}$ & 100 & 3 & 5 & 4.23 & .750 \\
\hline $\begin{array}{l}\text { Purchasing products \& get } \\
\text { accepted in term of religious } \\
\text { value }\end{array}$ & 100 & 2 & 5 & 3.78 & .690 \\
\hline $\begin{array}{l}\text { Religious value as inspirational } \\
\text { factor }\end{array}$ & 100 & 2 & 5 & 3.68 & .709 \\
\hline Valid N (list wise) & 100 & & & 3.86 & 0.72975 \\
\hline
\end{tabular}

Observation 6: Descriptive statistics shows that the obtained mean of the dimension religious value is 3.86. The highest mean has been obtained as 4.23 in case of Prohibited item purchase $\&$ religious value which is a very dominant factor in creating cognitive dissonance. The 
standard deviation score is 0.72975 , which means the variability among the dimension. Correlation matrix there shows hundred percent positive correlations among the entire questions variable \& all the four questions of this dimension have internal consistent relationship and also relationship has been derived in the responses of the purchasing pattern. There is a high degree of correlation between purchasing products \& get accepted in term of religious value \& religious value as inspirational factor. There is also correlation between Religious value as inspirational factor \& prohibited item purchase \& religious value but the degree of correlation is slightly lower.

Variance analysis also shows first two questions of the dimension covers $85.580 \%$ of the total variance. That represent that the first two questions are of great importance among all the questions of the dimensions.

\section{Correlations}

\begin{tabular}{|c|c|c|c|c|c|}
\hline & & $\begin{array}{l}\text { Religious } \\
\text { values \& } \\
\text { purchasing }\end{array}$ & $\begin{array}{l}\text { Prohibited } \\
\text { item purchase } \\
\& \quad \text { religious } \\
\text { value }\end{array}$ & $\begin{array}{l}\text { Purchasing } \\
\text { products \& } \\
\text { get accepted } \\
\text { in term of } \\
\text { religious } \\
\text { value }\end{array}$ & $\begin{array}{l}\text { Religious } \\
\text { value as } \\
\text { inspirational } \\
\text { factor }\end{array}$ \\
\hline $\begin{array}{l}\text { Religious values \& } \\
\text { purchasing }\end{array}$ & $\begin{array}{l}\text { Pearson Correlation } \\
\text { Sig. (2-tailed) } \\
\text { N }\end{array}$ & $\begin{array}{l}1 \\
\cdot \\
100\end{array}$ & $\begin{array}{l}.590(* *) \\
.000 \\
100\end{array}$ & $\begin{array}{l}.712(* *) \\
.000 \\
100\end{array}$ & $\begin{array}{l}.684(* *) \\
.000 \\
100\end{array}$ \\
\hline $\begin{array}{l}\text { Prohibited } \quad \text { item } \\
\text { purchase \& religious } \\
\text { value }\end{array}$ & $\begin{array}{l}\text { Pearson Correlation } \\
\text { Sig. (2-tailed) } \\
\text { N }\end{array}$ & $\begin{array}{l}.590(* *) \\
.000 \\
100\end{array}$ & $\begin{array}{l}1 \\
\cdot \\
100\end{array}$ & $\begin{array}{l}.547(* *) \\
.000 \\
100\end{array}$ & $\begin{array}{l}.520(* *) \\
.000 \\
100\end{array}$ \\
\hline $\begin{array}{l}\text { Purchasing products } \\
\& \text { get accepted in } \\
\text { term of religious } \\
\text { value } \\
\text { Religious value as } \\
\text { inspirational factor }\end{array}$ & $\begin{array}{l}\text { Pearson Correlation } \\
\text { Sig. (2-tailed) } \\
\text { N }\end{array}$ & $\begin{array}{l}.712(* *) \\
.000 \\
100 \\
.684\left(^{* *}\right) \\
.000 \\
100\end{array}$ & $\begin{array}{l}.547\left(^{* *}\right) \\
.000 \\
100 \\
.520(* *) \\
.000 \\
100\end{array}$ & $\begin{array}{l}1 \\
. \\
100 \\
.722(* *) \\
.000 \\
100\end{array}$ & $\begin{array}{l}.722(* *) \\
.000 \\
100 \\
1 \\
. \\
100\end{array}$ \\
\hline
\end{tabular}

** Correlation is significant at the 0.01 level (2-tailed) 


\section{Total Variance Explained}

\begin{tabular}{|l|l|l|l|l|l|l|}
\hline \multirow{2}{*}{ Component } & \multicolumn{3}{|l|}{ Initial Eigen values } & \multicolumn{3}{l|}{ Extraction Sums of Squared Loadings } \\
\cline { 2 - 7 } & Total & \% of Variance & Cumulative \% & Total & \% of Variance & Cumulative \% \\
\hline 1 & 2.895 & 72.385 & 72.385 & 2.895 & 72.385 & 72.385 \\
2 & .528 & 13.195 & 85.580 & & & \\
3 & .306 & 7.643 & 93.222 & & & \\
4 & .271 & 6.778 & 100.000 & & & \\
\hline
\end{tabular}

Extraction Method: Principal Component Analysis.

\subsection{Family Status Descriptive Statistics}

\begin{tabular}{|c|c|c|c|c|c|}
\hline & $\mathrm{N}$ & Minimum & Maximum & Mean & Std. Deviation \\
\hline $\begin{array}{l}\text { Purchasing items based on } \\
\text { family status }\end{array}$ & 100 & 2 & 5 & 3.94 & .583 \\
\hline $\begin{array}{l}\text { Importance of a products in } \\
\text { respect to family status }\end{array}$ & 100 & 2 & 5 & 4.25 & .702 \\
\hline Product's status & 100 & 1 & 5 & 3.96 & .751 \\
\hline $\begin{array}{l}\text { Eagerness of new products } \\
\text { with status }\end{array}$ & 100 & 1 & 5 & 3.85 & .809 \\
\hline Valid N (list wise) & 100 & & & 4 & 0.71125 \\
\hline
\end{tabular}

\section{Correlations}

\begin{tabular}{|c|c|c|c|c|c|}
\hline & & $\begin{array}{l}\text { Purchasing } \\
\text { items based } \\
\text { on family } \\
\text { status }\end{array}$ & $\begin{array}{l}\text { Importance of } \\
\text { a products in } \\
\text { respect to } \\
\text { family status }\end{array}$ & $\begin{array}{l}\text { Product's } \\
\text { status }\end{array}$ & $\begin{array}{l}\text { Eagerness of } \\
\text { new products } \\
\text { with status }\end{array}$ \\
\hline \multirow{3}{*}{$\begin{array}{l}\text { Purchasing items } \\
\text { based on family status }\end{array}$} & Pearson Correlation & 1 & $.333(* *)$ & $.202(*)$ & .195 \\
\hline & Sig. (2-tailed) & & .001 & .044 & .052 \\
\hline & $\mathrm{N}$ & 100 & 100 & 100 & 100 \\
\hline \multirow{3}{*}{$\begin{array}{l}\text { Importance of a } \\
\text { products in respect to } \\
\text { family status }\end{array}$} & Pearson Correlation & $.333(* *)$ & 1 & .019 & -.093 \\
\hline & Sig. (2-tailed) & .001 & . & .850 & .355 \\
\hline & $\mathrm{N}$ & 100 & 100 & 100 & 100 \\
\hline \multirow[t]{3}{*}{ Product's status } & Pearson Correlation & $.202(*)$ & .019 & 1 & $.655(* *)$ \\
\hline & Sig. (2-tailed) & .044 & .850 & . & .000 \\
\hline & $\mathrm{N}$ & 100 & 100 & 100 & 100 \\
\hline \multirow{3}{*}{$\begin{array}{l}\text { Eagerness of new } \\
\text { products with status }\end{array}$} & Pearson Correlation & .195 & -.093 & $.655(* *)$ & 1 \\
\hline & Sig. (2-tailed) & .052 & .355 & .000 & . \\
\hline & $\mathrm{N}$ & 100 & 100 & 100 & 100 \\
\hline
\end{tabular}


** Correlation is significant at the 0.01 level (2-tailed). * Correlation is significant at the 0.05 level (2-tailed).

\section{Total Variance Explained}

\begin{tabular}{|l|l|l|l|l|l|l|}
\hline \multirow{2}{*}{ Component } & \multicolumn{2}{l|}{ Initial Eigen values } & \multicolumn{3}{l|}{ Extraction Sums of Squared Loadings } \\
\cline { 2 - 6 } & Total & \% of Variance & Cumulative \% & Total & \% of Variance & Cumulative \% \\
\hline 1 & 1.766 & 44.152 & 44.152 & 1.766 & 44.152 & 44.152 \\
2 & 1.282 & 32.049 & 76.201 & 1.282 & 32.049 & 76.201 \\
3 & .620 & 15.495 & 91.695 & & & \\
4 & .332 & 8.305 & 100.000 & & & \\
\hline
\end{tabular}

Extraction Method: Principal Component Analysis.

Observation 7: Descriptive statistics shows that the obtained mean of the dimension family status is 4 . The highest mean has been obtained as 4.23 in case of importance of a product in respect to family status which is a very dominant factor in creating cognitive dissonance. The standard deviation score is 0.71125 , which means the variability among the dimension. The correlation matrix in this dimension shows both negative and positive correlation between the variables. There is a high degree of correlation between eagerness of new products with status \& product's status. There is also negative correlation between importance of a product in respect to family status \& eagerness of new products with status.

Variance analysis also shows first two questions of the dimension covers $76.201 \%$ of the total variance. That represent that the first two questions are of great importance among all the questions of the dimensions.

\subsection{Peer group influence Descriptive Statistics}

\begin{tabular}{|c|c|c|c|c|c|}
\hline & $\mathrm{N}$ & Minimum & Maximum & Mean & Std. Deviation \\
\hline $\begin{array}{l}\text { Influence of purchase on fellow } \\
\text { mate's comment }\end{array}$ & 100 & 1 & 5 & 2.78 & 1.236 \\
\hline $\begin{array}{l}\text { Finding of items that fellows } \\
\text { praise }\end{array}$ & 100 & 1 & 5 & 2.84 & 1.002 \\
\hline $\begin{array}{l}\text { Tasting of different brands as } \\
\text { being a source of information }\end{array}$ & 100 & 1 & 5 & 2.75 & 1.077 \\
\hline $\begin{array}{l}\text { Not giving value to fellow } \\
\text { mates comments }\end{array}$ & 100 & 1 & 5 & 3.14 & .921 \\
\hline Valid N (list wise) & 100 & & & 2.8775 & 1.059 \\
\hline
\end{tabular}




\section{Correlations}

\begin{tabular}{|c|c|c|c|c|c|}
\hline & & $\begin{array}{l}\text { Influence of } \\
\text { purchase on } \\
\text { fellow } \\
\text { mate's } \\
\text { comment }\end{array}$ & $\begin{array}{l}\text { Finding of } \\
\text { items that } \\
\text { fellows } \\
\text { praise }\end{array}$ & $\begin{array}{l}\text { Testing of } \\
\text { different } \\
\text { brands as } \\
\text { being a } \\
\text { source of } \\
\text { information }\end{array}$ & $\begin{array}{l}\text { Not giving } \\
\text { value to } \\
\text { fellow mates } \\
\text { comments }\end{array}$ \\
\hline \multirow{3}{*}{$\begin{array}{l}\text { Influence of purchase } \\
\text { on fellow mate's } \\
\text { comment }\end{array}$} & Pearson Correlation & 1 & $.795(* *)$ & $.801(* *)$ & $-.576(* *)$ \\
\hline & Sig. (2-tailed) & . & .000 & .000 & .000 \\
\hline & $\mathrm{N}$ & 100 & 100 & 100 & 100 \\
\hline \multirow{3}{*}{$\begin{array}{l}\text { Finding of items that } \\
\text { fellows praise }\end{array}$} & Pearson Correlation & $.795(* *)$ & 1 & $.852(* *)$ & $-.555(* *)$ \\
\hline & Sig. (2-tailed) & .000 & . & .000 & .000 \\
\hline & $\mathrm{N}$ & 100 & 100 & 100 & 100 \\
\hline \multirow{3}{*}{$\begin{array}{l}\text { Testing of different } \\
\text { brands as being a } \\
\text { source of information }\end{array}$} & Pearson Correlation & $.801(* *)$ & $.852(* *)$ & 1 & $-.606(* *)$ \\
\hline & Sig. (2-tailed) & .000 & .000 & . & .000 \\
\hline & $\mathrm{N}$ & 100 & 100 & 100 & 100 \\
\hline \multirow{3}{*}{$\begin{array}{l}\text { Not giving value to } \\
\text { fellow mates } \\
\text { comments }\end{array}$} & Pearson Correlation & $-.576(* *)$ & $-.555(* *)$ & $-.606(* *)$ & 1 \\
\hline & Sig. (2-tailed) & .000 & .000 & .000 & \\
\hline & $\mathrm{N}$ & 100 & 100 & 100 & 100 \\
\hline
\end{tabular}

** Correlation is significant at the 0.01 level (2-tailed).

Observation 8: Descriptive statistics shows that the obtained mean of the dimension peer group influence is 2.8775 which are pretty much lower. The highest mean has been obtained as 3.14 in case of not giving value to fellow mates comments which are a very dominant factor in creating cognitive dissonance. The standard deviation score is 1.059, which means the variability among the dimension. The correlation matrix in this dimension shows both negative and positive correlation between the variables. There is a high degree of correlation between testing of different brands as being a source of information \& finding of items that fellows praise. There is also high degree of negative correlation between testing of different brands as being a source of information \& not giving value to fellow mate's comments Variance analysis also shows first two questions of the dimension covers $90.878 \%$ of the total variance. That represent that the first two questions are of great importance among all the questions of the dimensions. 


\section{Al Macrothink}

\section{Total Variance Explained}

\begin{tabular}{|l|l|l|l|l|l|l|}
\hline \multirow{2}{*}{ Component } & \multicolumn{3}{|l|}{ Initial Eigen values } & \multicolumn{3}{l|}{ Extraction Sums of Squared Loadings } \\
\cline { 2 - 7 } & Total & \% of Variance & Cumulative \% & Total & \% of Variance & Cumulative \% \\
\hline 1 & 3.109 & 77.732 & 77.732 & 3.109 & 77.732 & 77.732 \\
2 & .526 & 13.146 & 90.878 & & & \\
3 & .220 & 5.490 & 96.368 & & & \\
4 & .145 & 3.632 & 100.000 & & & \\
\hline
\end{tabular}

Extraction Method: Principal Component Analysis.

\subsection{Emotional Reaction Descriptive Statistics}

\begin{tabular}{|c|c|c|c|c|c|}
\hline & $\mathrm{N}$ & Minimum & Maximum & Mean & Std. Deviation \\
\hline $\begin{array}{l}\text { Getting involved emotionally } \\
\text { in purchasing process }\end{array}$ & 100 & 1 & 5 & 3.19 & .907 \\
\hline $\begin{array}{l}\text { Can't help purchasing a } \\
\text { product that I like }\end{array}$ & 100 & 2 & 5 & 3.17 & .842 \\
\hline Stick to a familiar brand & 100 & 1 & 5 & 3.02 & .696 \\
\hline $\begin{array}{l}\text { Always buy something to make } \\
\text { myself feel better. }\end{array}$ & 100 & 1 & 5 & 2.74 & .895 \\
\hline Valid N (list wise) & 100 & & & 3.03 & 0.835 \\
\hline
\end{tabular}

Observation 9: Descriptive statistics shows that the obtained mean of the dimension emotional reaction is 3.03. The highest mean has been obtained as 3.19 in case of Getting involved emotionally in purchasing process which is a very dominant factor in creating cognitive dissonance. The standard deviation score is 0.835 , which means the variability among the dimension. Correlation matrix there shows hundred percent positive correlations among the entire questions variable \& all the four questions of this dimension have internal consistent relationship and also relationship has been derived in the responses of the purchasing pattern. There is a high degree of correlation between getting involved emotionally in purchasing process value \& can't help purchasing a product that I like Variance analysis also shows first two questions of the dimension covers $82.072 \%$ of the total variance. That represent that the first two questions are of great importance among all the questions of the dimensions. 


\section{Correlations}

\begin{tabular}{|c|c|c|c|c|c|}
\hline & & $\begin{array}{l}\text { Getting } \\
\text { involved } \\
\text { emotionally } \\
\text { in } \\
\text { purchasing } \\
\text { process }\end{array}$ & $\begin{array}{l}\text { Can't help } \\
\text { purchasing a } \\
\text { product that I } \\
\text { like }\end{array}$ & $\begin{array}{l}\text { Stick to a } \\
\text { familiar } \\
\text { brand }\end{array}$ & $\begin{array}{l}\text { Always buy } \\
\text { something to } \\
\text { make myself } \\
\text { feel better. }\end{array}$ \\
\hline \multirow{3}{*}{$\begin{array}{l}\text { Getting involved } \\
\text { emotionally } \\
\text { purchasing process }\end{array}$} & Pearson Correlation & 1 & $.752(* *)$ & $.410(* *)$ & $.460(* *)$ \\
\hline & Sig. (2-tailed) & . & .000 & .000 & .000 \\
\hline & $\mathrm{N}$ & 100 & 100 & 100 & 100 \\
\hline \multirow{3}{*}{$\begin{array}{l}\text { Can’t help purchasing } \\
\text { a product that I like }\end{array}$} & Pearson Correlation & $.752(* *)$ & 1 & $.339(* *)$ & $.636(* *)$ \\
\hline & Sig. (2-tailed) & .000 & . & .001 & .000 \\
\hline & $\mathrm{N}$ & 100 & 100 & 100 & 100 \\
\hline \multirow{3}{*}{$\begin{array}{l}\text { Stick to a familiar } \\
\text { brand }\end{array}$} & Pearson Correlation & $.410(* *)$ & $.339(* *)$ & 1 & $.219(*)$ \\
\hline & Sig. (2-tailed) & .000 & .001 & . & .028 \\
\hline & $\mathrm{N}$ & 100 & 100 & 100 & 100 \\
\hline \multirow{3}{*}{$\begin{array}{l}\text { Always buy something } \\
\text { to make myself feel } \\
\text { better. }\end{array}$} & Pearson Correlation & $.460(* *)$ & $.636(* *)$ & $.219(*)$ & 1 \\
\hline & Sig. (2-tailed) & .000 & .000 & .028 & . \\
\hline & $\mathrm{N}$ & 100 & 100 & 100 & 100 \\
\hline
\end{tabular}

** Correlation is significant at the 0.01 level (2-tailed). * Correlation is significant at the 0.05 level (2-tailed).

\section{Total Variance Explained}

\begin{tabular}{|l|l|l|l|l|l|l|}
\hline \multirow{2}{*}{ Component } & \multicolumn{3}{|l|}{ Initial Eigen values } & \multicolumn{3}{l|}{ Extraction Sums of Squared Loadings } \\
\cline { 2 - 7 } & Total & \% of Variance & Cumulative \% & Total & \% of Variance & Cumulative \% \\
\hline 1 & 2.458 & 61.449 & 61.449 & 2.458 & 61.449 & 61.449 \\
2 & .825 & 20.623 & 82.072 & & & \\
4 & .509 & 12.732 & 94.804 & & & \\
4 & .208 & 5.196 & 100.000 & & & \\
\hline
\end{tabular}

Extraction Method: Principal Component Analysis. 


\section{Personal performances}

\begin{tabular}{|c|c|c|c|c|c|}
\hline & $\mathrm{N}$ & Minimum & Maximum & Mean & Std. Deviation \\
\hline $\begin{array}{l}\text { Paying more for a higher status } \\
\text { product }\end{array}$ & 100 & 2 & 5 & 3.64 & .718 \\
\hline $\begin{array}{l}\text { Always go for higher status } \\
\text { products. }\end{array}$ & 100 & 2 & 5 & 3.64 & .772 \\
\hline $\begin{array}{l}\text { Avoiding products that mismatch } \\
\text { with my personality }\end{array}$ & 100 & 3 & 5 & 3.55 & .626 \\
\hline $\begin{array}{l}\text { Products influence our career \& } \\
\text { performance }\end{array}$ & 100 & 2 & 5 & 3.01 & .732 \\
\hline Valid N (list wise) & 100 & & & 3.46 & 0.712 \\
\hline
\end{tabular}

\section{Descriptive statistics}

\section{Correlations}

\begin{tabular}{|c|c|c|c|c|c|}
\hline & & $\begin{array}{l}\text { Paying more } \\
\text { for a higher } \\
\text { status product }\end{array}$ & $\begin{array}{l}\text { Always go for } \\
\text { higher status } \\
\text { products. }\end{array}$ & $\begin{array}{l}\text { Avoiding products } \\
\text { that mismatch with } \\
\text { my personality }\end{array}$ & $\begin{array}{l}\text { Products influence } \\
\text { our career \& } \\
\text { performance }\end{array}$ \\
\hline \multirow{3}{*}{$\begin{array}{ll}\text { Paying more } & \text { for a } \\
\text { higher } & \text { status } \\
\text { product } & \end{array}$} & $\begin{array}{l}\text { Pearson } \\
\text { Correlation }\end{array}$ & 1 & $.565(* *)$ & $.648(* *)$ & $.545(* *)$ \\
\hline & $\begin{array}{l}\text { Sig. } \\
\text { (2-tailed) }\end{array}$ & . & .000 & .000 & .000 \\
\hline & $\mathrm{N}$ & 100 & 100 & 100 & 100 \\
\hline \multirow{3}{*}{$\begin{array}{lrr}\text { Always } & \text { go } & \text { for } \\
\text { higher } & \text { status } \\
\text { products. } & & \end{array}$} & $\begin{array}{l}\text { Pearson } \\
\text { Correlation }\end{array}$ & $.565(* *)$ & 1 & $.539(* *)$ & $.543(* *)$ \\
\hline & $\begin{array}{l}\text { Sig. } \\
\text { (2-tailed) }\end{array}$ & .000 & . & .000 & .000 \\
\hline & $\mathrm{N}$ & 100 & 100 & 100 & 100 \\
\hline \multirow{3}{*}{$\begin{array}{l}\text { Avoiding products } \\
\text { that mismatch with } \\
\text { my personality }\end{array}$} & $\begin{array}{l}\text { Pearson } \\
\text { Correlation }\end{array}$ & $.648(* *)$ & $.539(* *)$ & 1 & $.451(* *)$ \\
\hline & $\begin{array}{l}\text { Sig. } \\
\text { (2-tailed) }\end{array}$ & .000 & .000 & . & .000 \\
\hline & $\mathrm{N}$ & 100 & 100 & 100 & 100 \\
\hline \multirow{3}{*}{$\begin{array}{l}\text { Products influence } \\
\text { our career \& } \\
\text { performance }\end{array}$} & $\begin{array}{l}\text { Pearson } \\
\text { Correlation }\end{array}$ & $.545(* *)$ & $.543(* *)$ & $.451(* *)$ & 1 \\
\hline & $\begin{array}{l}\text { Sig. } \\
\text { (2-tailed) }\end{array}$ & .000 & .000 & .000 & . \\
\hline & $\mathrm{N}$ & 100 & 100 & 100 & 100 \\
\hline
\end{tabular}

** Correlation is significant at the 0.01 level (2-tailed). 


\section{$\Lambda$ Macrothink}

Total Variance Explained

\begin{tabular}{|l|l|l|l|l|l|l|}
\hline \multirow{2}{*}{ Component } & \multicolumn{3}{|l|}{ Initial Eigen values } & \multicolumn{3}{l|}{ Extraction Sums of Squared Loadings } \\
\cline { 2 - 7 } & Total & \% of Variance & Cumulative \% & Total & \% of Variance & Cumulative \% \\
\hline 1 & 2.649 & 66.216 & 66.216 & 2.649 & 66.216 & 66.216 \\
2 & .570 & 14.248 & 80.465 & & & \\
3 & .445 & 11.131 & 91.595 & & & \\
4 & .336 & 8.405 & 100.000 & & & \\
\hline
\end{tabular}

Extraction Method: Principal Component Analysis.

Observation 10: Descriptive statistics shows that the obtained mean of the dimension personal performance is 3.46. The highest mean has been obtained as 3.64 in case of paying more for a higher status product \& always go for higher status products which are very significant factors in creating cognitive dissonance. The standard deviation score is 0.712 , which means the variability among the dimension. Correlation matrix there shows hundred percent positive correlations among the entire questions variable \& all the four questions of this dimension have internal consistent relationship and also relationship has been derived in the responses of the purchasing pattern. There is a high degree of correlation between avoiding products that mismatch with my personality \& paying more for a higher status product. Variance analysis also shows first two questions of the dimension covers $80.465 \%$ of the total variance. That represent that the first two questions are of great importance among all the questions of the dimensions.

\section{Conclusion and Recommendations}

\subsection{Conclusion}

The study was conducted in the Khulna metropolitan area to find out the factors affecting cognitive dissonance among the consumer goods buyers. The results of this study illustrated that some factors e.g. norms, religious values, cultures, customs etc are responsible for creating cognitive dissonance among the customers. The findings would be an eye opener to various marketers and academicians to know the importance of Cognitive Dissonance for making a customer as satisfied or dissatisfied. This study also has suggested some strategy which service organization might reduce cognitive dissonance. Today with the rapid growth of service industry marketers of different service organizations are facing huge challenges to meet up customers expectations. Therefore it is important for the service organization to reduce dissonance related to purchasing and thus survive in the competition in the local as well as in the global markets.

\subsection{Recommendations}

After analyzing the outcome of the survey analysis the study has recommended some of the strategies which might be effective in reducing cognitive dissonance. These are: 
$\checkmark$ Focus on more encouraging beliefs that offset the dissonant belief or behavior.

$\checkmark$ Reduce the importance of the contradictory belief.

$\checkmark$ Change the conflicting belief so that it is consistent with other beliefs or behaviors.

$\checkmark$ Looking for credible source which the target consumers trust. At the same time word-of-mouth communications need to be increased.

$\checkmark$ Emphasize on selecting a likeable source.

$\checkmark$ Messages that will be delivered to the customers should be free from any complexity.

$\checkmark \quad$ Finding out the sources which match customer's previous belief.

$\checkmark$ Introduction of celebrity as delivering target messages.

$\checkmark \quad$ Unexpected source sometimes may have more impact on consumer’s attitudes.

$\checkmark$ Anything that is prohibited by the religion of the majority should be avoided since the study has found that customers are more sensitive to their religion.

$\checkmark \quad$ Marketers can segment their markets based on different classes of the society and then deliver messages and services based on their respective personality.

\section{References}

Assael, H. (1981), Consumer Behavior and Marketing Action, (3rd Edition), PWS-Kent Publishing Company, Boston, M. A.

Berkman, H. W. (1992). Twenty years of the journal. Journal of the Academy of Marketing Science, 20(4), 299-300. http://dx.doi.org/10.1007/BF02725204

Cognitive dissonance. (2012). In Wikipedia. Retrieved March 14, from en.wikipedia.org/wiki/Cognitive dissonance

Davis, Keith A., \& John W. Newstrom (2000). Human Behavior at Work: Organizational Behavior. New York: McGraw-Hill, current edition.

Ekinci, Y., \& Riley, M. (2003). An Investigation of Self-concept: Actual and Ideal Self congruence Compared in the Context of Service Evaluation. Journal of Retailing and Consumer Services, 10, 201-14. http://dx.doi.org/10.1016/S0969-6989(02)00008-5

Engel, J F. (1998). Consumer Behavior. Blackwell R.D. \&Miniard P.W. Dryden.p-789.

Festinger, L. (1957). A Theory of Cognitive Dissonance. Stanford University Press, California. Retrieved February 2, 2011 from www.books.google.com

Grimm, P. E. (2005). Ab components' impact on brand performance. Journal of Business Research, 58(4), 508-517. http://dx.doi.org/10.1016/S0148-2963(03)00141-3

Hamza V. K., \& Zakkariya K. A. (2012). Determinants of cognitive dissonance and its relative importance to consumer product purchase. International Journal of Multidisciplinary 
Management Studies, 2(1), January 2012, ISSN 22498834.

Hawkins DI; Best, R J., \& Coney, K. A. (1989). Consumer Behavior: Implications for Marketing Strategy. Homewood, Boston: BPI/IRWIN. P-433

Hitesh Bhasin. (2010). "=Factors Affecting Consumer Buying Behavior. From www.marketing91.com

Icek, Ajzen. (2001). Nature and Operation of Attitudes. Annual Reviews. 52:27-58

Kaish, S. (1967). Cognitive Dissonance and the Classification of Consumer Goods. The Journal of Marketing, 31(4), 28-31. http://dx.doi.org/10.2307/1249462

Korgaonkar, K. P., \& Moschis, G. P. (1982). An Experimental Study of Cognitive Dissonance, Product Involvement, Expectations, Performance and Consumer Judgment of Product Performance. Journal of Advertising, 11(3), 32-44.

Loudon, D.L. (1993). Consumer Behavior. Concepts and Applications / D.L. Loudon, A.J. Della Bitta. McGraw-Hill, Inc., p. 788.

Louisa C. Egan, Laurie R. Santos, \& Paul Bloom. (2007). The Origins of Cognitive Dissonance Evidence From Children and Monkeys. Research article, 18(11), Association for Psychological Science.

Malhotra, N. (2005). Attitude and affect: new frontiers of research in the 21st century. Journal of Business Research, 477-482. http://dx.doi.org/10.1016/S0148-2963(03)00146-2

Matthew D. Lieberman, Kevin N. Ochsner, Daniel T. Gilbert, \& Daniel L. Schacter, (2001). Do Amnesics Exhibit Cognitive Dissonance Reduction? The Role of Explicit Memory and Attention in Attitude Change. Research article, 12(2), March 2000.

Montgomery, C., \& Barnes, J.H. (1993). POSTDIS: A Short Rating Scale for Measuring Post Purchase Dissonance. Journal of Consumer Satisfaction, Dissatisfaction and Complaining Behavior, 6, 204-216.

Rice, Ch. (1997). Understanding Customers Butterworth-Heinemann, 216 p.

Schiffman, L.G. (2004). Consumer Behavior, L.G. Schiffman, L.L. Kanuk. Prentice Hall, p. 250-287

Sirgy, M. J., Johar, S., \& Claiborne, C. B. (1992). Self-concept Motivation as Mediator between Self-congruity and Attitude/Intention. Developments in Marketing Science, 15, 402-406.

Solomon R. Michael. (2004). Consumer Behavior: Buying, Having, and Being. Singapore: Pearson Prentice Hall. P 224-244.

Solomon, M. Michael. (2002). Consumer Behavior. A European Perspective, M. Solomon, G. Bamossy, S. Askegaard.Prentice Hall, p.126-153. 
Wang, Yun, \& Heitmeyer, Jeanne (2005). Consumer Attitude toward US versus Domestic Apparel in Taiwan. International Journal of Consumer Studies, 30(1), 64-74. http://dx.doi.org/10.1111/j.1470-6431.2005.00450.x 